\title{
Hematological profile of captive bearded capuchin monkeys (Sapajus libidinosus) from Northeastern Brazil
}

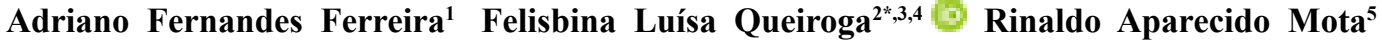 \\ Eneida Willcox Rêgo ${ }^{5}$ Stéphanie Machado Mota ${ }^{2}$ Magda Guedes Teixeira ${ }^{2}$ Aura Colaço ${ }^{2,6}$
}

${ }^{1}$ Universidade Federal de Campina Grande (UFCG), Patos, PB, Brasil.

${ }^{2}$ Department of Veterinary Sciences, University of Trás-os-Montes and Alto Douro, 5000-801, Vila Real, Portugal. E-mail:fqueirog@utad.pt. ${ }^{*}$ Corresponding author.

${ }^{3}$ Center for Research and Technology of Agro-Environment and Biological Sciences (CITAB), University of Trás-os-Montes and Alto Douro, Vila Real, Portugal.

${ }^{4}$ Center for the Study of Animal Sciences, CECA-ICETA, University of Porto, Porto, Portugal.

${ }^{5}$ Universidade Federal Rural de Pernambuco (UFRPE), Dois Irmãos, PE, Brasil.

${ }^{6} \mathrm{CECAV}$, University of Trás-os-Montes and Alto Douro, Vila Real, Portugal.

ABSTRACT: Bearded Capuchin or Black-striped Capuchin monkeys (Sapajus lidibinosus) are New World robust capuchin monkeys widely used in medical research. Few data are available concerning hematological reference values for these species, with no studies available from the Northeast region in Brazil. The aim of this study was to determine the hematological reference values for healthy bearded capuchin monkeys and to analyze the influence of sex and age factors. Blood samples were collected from 50 healthy bearded capuchin monkeys housed in captivity. These were analysed for total erythrocyte, hemoglobin, leukocyte and platelet count, packed cell volume (PCV), mean corpuscular volume $(\mathrm{MCV})$, mean corpuscular hemoglobin $(\mathrm{MCH})$ and mean corpuscular hemoglobin concentration (MCHC). When considering the age factor, significant differences were reported for total erythrocyte count, PCV, hemoglobin, total leucocytes, band neutrophils, eosinophils and lymphocytes (higher in juveniles). Significant sex-associated differences were noted for total erythrocyte count, PCV, hemoglobin (higher in males) and number of lymphocytes (higher in females). We have reported for the first time the hematological profile of bearded capuchin monkeys in captivity in the state of Paraiba, Brazil. These results can contribute for a better understanding of the normal physiology of capuchin monkeys, while demonstrating that factors such as sex and age influence hematological parameters should be taken into consideration in the hematological evaluation of this species.

Key words: Sapajus libidinosus, hematology, blood parameters, Reference interval.

Perfil hematológico de macacos-prego (Sapajus libidinosus) do nordeste do Brasil

RESUMO: Os macacos-prego (Sapajus lidibinosus) são macacos capuchinhos robustos do Novo Mundo amplamente utilizados na pesquisa médica. Poucos dados estão disponíveis sobre valores de referência hematológicos para essas espécies, e não há estudos na região Nordeste no Brasil. O nosso objetivo foi determinar os valores de referência hematológicos para macacos-prego saudáveis e analisar a influência de fatores como o sexo e a idade. Foram coletadas amostras de sangue de 50 macacos-prego saudáveis alojados em cativeiro. Determinaram-se as contagens de eritrócitos, hemoglobina, leucócitos e plaquetas, hematócrito, volume corpuscular médio (MCV), hemoglobina corpuscular média (MCH) e concentração média de hemoglobina corpuscular (MCHC). Foram encontradas diferenças significativas relacionadas à idade para a contagem total de eritrócitos, hematócrito, hemoglobina, leucócitos totais, neutrófilos em banda, eosinófilos e linfócitos (maior em juvenis). Diferenças significativas associadas ao sexo foram observadas para a contagem total de eritrócitos, hematócrito, hemoglobina (maior nos machos) e número de linfócitos (maior nas fêmeas). Relatamos o primeiro perfil hematológico de macacos-prego alojados em cativeiro no estado da Paraíba, Brasil. Estes resultados contribuem para uma melhor compreensão da normal fisiologia dos macacos-prego e demonstram que fatores como sexo e a idade têm influência e devem ser considerados na sua avaliação hematológica.

Palavras-chave: Sapajus libidinosus, hematologia, parâmetros sanguíneos, intervalo de referência.

\section{INTRODUCTION}

Cebus libidinosus, New World tufted capuchin monkeys, were reclassified in 2015 as Sapajus libidinosus, after a phylogenetic reconstruction (MARTINS et al., 2015).
Capuchin monkeys are widely used in medical research, especially in areas such as immunology, pharmacology, physiology and neuroscience (TERPSTRA et al, 1991; LARSSON et al.,1997).

Clinical and laboratory tests are highly important to ensure their good health and wellbeing 
conditions. Among the laboratory tests, hematology tests stand out as an important tool, assisting clinicians in evaluating the animal's health status and guiding them in establishing a diagnosis, prognosis and the adoption of appropriated therapies (KENNEDY et al., 1997).

Despite the scientific community's interest in working with non-human primates as experimental models, information about the reference values is scarce, and, mostly concerning Old World monkeys, such as rhesus monkeys, as well as chimpanzees (BUCHL, HOWARD, 1997; IHRIG et al., 2001). There are a few studies in the literature involving bearded capuchin monkeys, such as ROSNER and colleagues (1986), in Paraguay, RIVIELLO \& WIRZ (2001), in Italy and NUNES and collaborators (2008), in Chile. However, to the best of our knowledge, there are no studies from the Northeastern region of Brazil. The one research concerning bearded capuchin monkeys in Brazil was carried out in the Southern region, more than $3000 \mathrm{~km}$ from the Northeast (FLAIBAN, 2008). Considering regional differences related to climate (temperature and humidity), values obtained in that region may not be applicable to the reality of the Northeastern region. Thus, the aim of the present study was to determine the hematological profile of bearded capuchin monkeys maintained in captivity in the state of Paraiba, located in the Northeastern region of Brazil, and to search for possible variations in hematological values related to sex and age.

\section{MATERIALS AND METHODS}

\section{Animals}

Blood samples were collected from 50 bearded capuchin monkeys (Sapajus lidibinosus) maintained in captivity in the Screening Center for Wild Animals of the Brazilian Institute of Environment and Renewable Natural Resources in the Town of Cabedelo/State of Paraíba, Brazil. Animals were considered healthy on the basis of a physical examination, body temperature, and hair condition. In addition, they lived under similar sanitary, nutritional and environmental conditions. Animals were grouphoused in clean indoor-outdoor primate facilities and fed twice a day with local fruits and vegetables, and a freely available water supply.

To define the juvenile and adult groups, an estimation of the animal's age was performed, following the criteria described previously by FRAGASZY (2004). Animals were divided into groups, according to sex and age, and the groups were compared as follows: adults $(n=37)$ juveniles $(n=13)$, males $(n=25) /$ females $(n=25)$, juvenile males $(n=5) /$ adult males $(n=20)$; juvenile females $(n=8) /$ adult females $(n=17)$; juvenile males $(n=5) /$ juvenile females $(n=8)$; adult males $(n=20)$ /adult females $(n=17)$.

\section{Blood sampling and hematological determinations}

After an overnight fasting of $\geq 8$ hours, each monkey was sedated with a cocktail of ketamine $\left(10 \mathrm{mg} / \mathrm{kg}\right.$; Dopalen ${ }^{\circledR}$, Ceva, Brazil), xylazine $\left(2 \mathrm{mg} / \mathrm{kg} ;\right.$ Virbaxyl $^{\circledR}$, Virbac, Brazil) and diazepam (1mg/kg; Valium ${ }^{\circledR}$, Roche, Brazil), administered intramuscularly. After sedation, $3 \mathrm{ml}$ of blood was collected from the femoral vein of each animal, by using disposable $12 \times 8$ inch syringes and 22-gauge needles.

Samples were then placed into a $1 \mathrm{mLEDTA}$ K3 container (IDEXX Vetcollect) for a complete blood count (total erythrocyte count [red blood cells - RBC], packed cell volume (PCV), hemoglobin, leukocytes [White blood cells - WBC] and platelets) and RBC indexes: mean corpuscular volume (MCV), mean corpuscular hemoglobin $(\mathrm{MCH})$ and mean corpuscular hemoglobin concentration (MCHC).

Total erythrocytes and leukocytes counts were made in a Neubauer chamber. Each one was counted twice, and then, the mean value was calculated. The PCV was obtained by micro centrifugation at $12,000 \mathrm{rpm}$ and the hemoglobin concentration by using the cyanometa hemoglobin method (THEML, 2004). Values for the MCV and $\mathrm{MCHC}$ indexes were then calculated. Blood smears were prepared, air dried and stained with a modified Romanowsky stain (Rapi-Diff II Stain Kit,

Atom Scientific, Manchester), a staining protocol for the differential leukocytes count. After that, two blood smears were analyzed, with 100 cells were counted in each one of them, and the mean value was calculated. Platelet count was performed using the Fonio's method (FONIO, 1992).

\section{Statistical analysis}

The calculations of basic descriptive statistics, RI and their confidence interval limits (90\%) were performed with the Reference Value Advisor V 2.1 software, a free set of macroinstructions to calculate RI with Microsoft Excel (GEFFRÉ et al., 2011). The RI were estimated following the ASVCP guidelines (FRIEDRICHS et al., 2012), namely those recommended for samples size $(\mathrm{x})$ included in the interval $40 \leq \mathrm{x}<120$.

The SPSS software (Statistical Package for the Social Sciences, Chicago, IL, USA) version 20.0 was 
also used for statistical analysis. Data were subjected to the analysis of variance (univariate ANOVA) and the Fisher test was used to evaluate whether sex differences existed within each age category and whether age differences existed within each sex category. All values were expressed as mean and standard deviation (SD). In all statistical comparisons, $\mathrm{P}<0.05$ was accepted as denoting a significant difference.

\section{RESULTS}

The hematological profile of 50 healthy bearded capuchin monkeys (Sapajus libidinosus), are present in table 1. In order to examine the impact of sex and age, we compared subgroups. Parameters with statistically significant differences between subgroups are reported in table 2 .

Significant sex-associated differences were noted for the total erythrocyte count, PCV, hemoglobin (higher in males) and the number of lymphocytes (higher in females). The same differences were reported comparing adult males and adult females. Significant differences for hematological variables between juvenile males and juvenile females were reported for hemoglobin concentration (higher in juvenile males) (Table 2). We also found a tendency for higher values of $\mathrm{RBC}$ in juvenile males $(\mathrm{P}=0.06)$, compared to juvenile females.

Significant differences related to age were also reported for the total erythrocyte count, PCV, hemoglobin, total leucocytes, band neutrophils, eosinophils and lymphocytes (higher in juveniles). The same significant differences were seen between juvenile males and adult males (higher values in juvenile males) and between juvenile females and adult females (higher values in juvenile females) (Table 2).

\section{DISCUSSION}

\section{Sex-associated differences}

Regarding sex, differences were found for PCV, hemoglobin (higher in males) and number of lymphocytes (higher in females). Higher values of the total erythrocyte count in males were in accordance with previous studies performed in capuchin monkeys (ROSNER et al., 1986; WIRZ et al., 2008), as in other nonhuman primates (RAHAMAN et al., 1975; JAIN, 1993; VIDEAN et al., 2008). The lower erythrocyte value obtained in females can be due to the hormonal influence of estrogens. These hormones can have an inhibitory action on the erythropoiesis (BLOBEL, ORKIN, 1996; WIRZ et al., 2008). Menstrual cycle can also have an additional effect, as this species has a relatively short menstruating cycle (20 days) (CAROSI, et al., 1999). Higher hemoglobin values observed in males can be attributed to the fact that males have a greater muscle mass than females, thus a greater demand for hemoglobin to carry out the adequate supply of oxygen to the tissues (IHRIG, 2001).

Table 1 - Hematologic parameters from 50 bearded capuchin monkeys (Sapajus libidinosus).

\begin{tabular}{|c|c|c|c|c|c|c|c|}
\hline $\begin{array}{l}\text { Parameter (International } \\
\text { Systems of Units) }\end{array}$ & Mean & SD & Median & Min.-Max. & RI & LRL $90 \% \mathrm{CI}$ & URL $90 \% \mathrm{CI}$ \\
\hline Erythrocytes $\left(\mathrm{x} 10^{12} / \mathrm{L}\right)$ & 5.65 & 0.97 & 5.75 & $3.76-8.12$ & $3.66-7.64$ & $3.30-4.04$ & $7.24-8.02$ \\
\hline PCV & 0.39 & 0.31 & 0.39 & $0.32-0.46$ & $0.32-0.45$ & $0.31-0.33$ & $0.43-0.46$ \\
\hline Hemoglobin $(g / L)$ & 121.00 & 13.00 & 121.00 & $95.00-161.00$ & $95.00-147.00$ & $89.00-100.00$ & $142.00-152.00$ \\
\hline Mean corpuscular volume (fL) & 69.70 & 10.00 & 68.10 & $50.49-98.40$ & $49.30-90.10$ & $45.30-53.70$ & $86.00-94.10$ \\
\hline $\begin{array}{l}\text { Mean corpuscular hemoglobin } \\
\text { concentration }(\%)\end{array}$ & 31.40 & 2.20 & 31.40 & $27.14-40.25$ & $26.80-35.90$ & $25.90-27.80$ & $34.90-36.80$ \\
\hline Leucocytes $\left(\times 10^{9} / \mathrm{L}\right)$ & 9.70 & 3.88 & 8.67 & $3.85-18.90$ & $3.92-18.69$ & $3.85-5.00$ & $16.37-18.90$ \\
\hline Band neutrophils $\left(\times 10^{9} / \mathrm{L}\right)$ & 7.57 & 0.11 & 0.00 & $0.00-0.44$ & $0.00-0.41$ & $0.00-0.00$ & $0.28-0.44$ \\
\hline Segmented neutrophils $\left(\times 10^{9} / \mathrm{L}\right)$ & 4.93 & 3.24 & 4.04 & $1.04-14.36$ & $1.11-14.31$ & $1.04-1.68$ & $11.02-14.36$ \\
\hline Eosinophils $\left(\times 10^{9} / \mathrm{L}\right)$ & 0.21 & 0.33 & 0.09 & $0.00-1.62$ & $0.00-1.52$ & $0.00-0.00$ & $0.83-1.62$ \\
\hline Basophils $\left(\times 10^{9} / \mathrm{L}\right)$ & 0.01 & 0.03 & 0.00 & $0.00-0.15$ & $0.00-0.13$ & $0.00-0.00$ & $0.07-0.15$ \\
\hline Lymphocytes $\left(\mathrm{x} 10^{9} / \mathrm{L}\right)$ & 4.08 & 2.23 & 3.456 & $0.00-9.36$ & $0.33-9.26$ & $0.00-1.60$ & $8.64-9.36$ \\
\hline Monocytes $\left(\times 10^{9} / \mathrm{L}\right)$ & 0.46 & 0.87 & 0.27 & $0.00-4.900$ & $0.00-4.67$ & $0.00-0.00$ & $1.152-4.00$ \\
\hline Platelets $\left(\times 10^{9} / \mathrm{L}\right)$ & 270.72 & 52.12 & 268.60 & $169.20-406.00$ & $164.93-376.51$ & $143.82-186.25$ & $353.33-397.93$ \\
\hline
\end{tabular}

PCV - packed cell volume; SD-Standard deviations; Min-minimum; Max - Maximum; RI-Reference interval; LRL - lower reference limit; URL -upper reference limit; $90 \% \mathrm{CI}$ - confidence interval around the limit. 
Table 2 - Hematological variables from 50 bearded capuchin monkeys (Sapajus. libidinosus) with statistically significant differences, between groups $(\mathrm{P}<0.05)$.

\begin{tabular}{|c|c|c|c|c|}
\hline Category & Analyte (International Systems of Units) & Mean (SD) & Mean (SD) & $P$ \\
\hline \multirow{12}{*}{ Sex } & & Total Males $(\mathrm{N}=25)$ & Total Females $(\mathrm{N}=25)$ & \\
\hline & Erythrocytes $\left(\times 10^{12} / \mathrm{L}\right)$ & $6.22(0.92)$ & $5.21(0.85)$ & 0.001 \\
\hline & PCV & $0.40(0.22)$ & $0.38(0.36)$ & 0.006 \\
\hline & Hemoglobin $(\mathrm{g} / \mathrm{L})$ & $129.1(12.10)$ & $117.3(13.70)$ & 0.002 \\
\hline & Lymphocytes $\left(\times 10^{9} / \mathrm{L}\right)$ & $3.38(1.86)$ & $4.79(2.37)$ & 0.023 \\
\hline & & Adult males $(\mathrm{N}=20)$ & Adult females $(\mathrm{N}=17)$ & \\
\hline & Erythrocytes $\left(\times 10^{12} / \mathrm{L}\right)$ & $6.02(0.89)$ & $4.89(0.54)$ & $<0.001$ \\
\hline & PCV & $0.40(0.19)$ & $0.33(0.20)$ & $<0.001$ \\
\hline & Hemoglobin $(\mathrm{g} / \mathrm{L})$ & $125.40(10.00)$ & $109.00(7.60)$ & $<0.001$ \\
\hline & Lymphocytes $\left(\times 10^{9} / \mathrm{L}\right)$ & $2.68(1.06)$ & $4.03(1.95)$ & 0.012 \\
\hline & & Juvenile males $(\mathrm{N}=5)$ & Juvenile females $(\mathrm{N}=8)$ & \\
\hline & Hemoglobin $(g / L)$ & $144.0(7.5)$ & $122.1(19.6)$ & 0.039 \\
\hline \multirow{24}{*}{ Age } & & Adults $(\mathrm{N}=37)$ & Juveniles $(\mathrm{N}=13)$ & \\
\hline & Erythrocytes $\left(\times 10^{12} / \mathrm{L}\right)$ & $5.50(0.93)$ & $6.32(1.02)$ & 0.011 \\
\hline & PCV & $0.38(0.26)$ & $0.40(0.43)$ & 0.036 \\
\hline & Hemoglobin $(g / L)$ & $120.6(11.10)$ & $130.5(19.10)$ & 0.029 \\
\hline & Leucocytes $\left(\times 10^{9} / \mathrm{L}\right)$ & $9.04(3.74)$ & $11.57(3.80)$ & 0.042 \\
\hline & Band Neutrophils $\left(\times 10^{9} / \mathrm{L}\right)$ & $0.05(0.08)$ & $0.14(0.16)$ & 0.015 \\
\hline & Eosinophils $\left(\times 10^{9} / \mathrm{L}\right)$ & $0.12(0.13)$ & $0.48(0.53)$ & 0.001 \\
\hline & Lymphocytes $\left(\times 10^{9} / \mathrm{L}\right)$ & $3.66(2.03)$ & $5.29(2.42)$ & 0.022 \\
\hline & & Adult males $(\mathrm{N}=20)$ & Juvenile males $(\mathrm{N}=5)$ & \\
\hline & Erythrocytes $\left(\mathrm{x} 10^{12} / \mathrm{L}\right)$ & $6.02(0.89)$ & $6.99(0.68)$ & 0.035 \\
\hline & $\mathrm{PCV}$ & $0.40(0.19)$ & $0.42(0.19)$ & 0.009 \\
\hline & Hemoglobin (g/L) & $125.4(10.00)$ & $144.0(7.50)$ & 0.001 \\
\hline & Leucocytes $\left(\times 10^{9} / \mathrm{L}\right)$ & $8.55(3.86)$ & $12.91(3.67)$ & 0.032 \\
\hline & Band Neutrophils $\left(\times 10^{9} / \mathrm{L}\right)$ & $0.05(0.09)$ & $0.07(0.12)$ & 0.048 \\
\hline & Eosinophils $\left(\times 10^{9} / \mathrm{L}\right)$ & $0.09(0.01)$ & $0.45(0.53)$ & 0.007 \\
\hline & Lymphocytes $\left(\times 10^{9} / \mathrm{L}\right)$ & $2.68(1.06)$ & $5.07(3.30)$ & 0.009 \\
\hline & & Adult females $(\mathrm{N}=17)$ & Juvenile females $(\mathrm{N}=8)$ & \\
\hline & Erythrocytes $\left(\mathrm{x} 10^{12} / \mathrm{L}\right)$ & $4.89(0.54)$ & $5.90(1.01)$ & 0.003 \\
\hline & PCV & $0.33(0.20)$ & $0.39(0.51)$ & 0.001 \\
\hline & Hemoglobin $(\mathrm{g} / \mathrm{L})$ & $109.0(7.60)$ & $122.1(19.60)$ & 0.024 \\
\hline & Leucocytes $\left(\times 10^{9} / \mathrm{L}\right)$ & $9.62(3.6)$ & $12.366(3.23)$ & 0.042 \\
\hline & Band Neutrophils $\left(\times 10^{9} / \mathrm{L}\right)$ & $0.05(0.08)$ & $0.19(0.17)$ & 0.011 \\
\hline & Eosinophils $\left(\times 10^{9} / \mathrm{L}\right)$ & $0.15(1.36)$ & $0.50(0.57)$ & 0.023 \\
\hline & Lymphocytes $\left(\times 10^{9} / \mathrm{L}\right)$ & $4.03(1.95)$ & $6.61(2.02)$ & 0.006 \\
\hline
\end{tabular}

The higher number of circulating lymphocytes in females has not been previously described in these species (FLAIBAN et al., 2008; WIRZ et al., 2008). NUNN and collaborators (2000) observed that white blood cell counts were significantly higher in nonhuman primates whose females have more mating partners. These authors hypothesized that the high risk of sexually transmitted diseases is probably a major factor leading to systematic differences in the primate immune system (NUNN et al, 2000). Although, female capuchin monkeys do not exhibit a truly polygamic behavior, a female can occasionally accept other males during the fertile period. However, we could not rule out the possible effect of climatic environment, food and even local antigen stimulation, requiring further studies to confirm this fact. 


\section{Age-related differences}

The total erythrocyte count, PCV, hemoglobin, total leucocytes, band neutrophils, eosinophils and lymphocytes were higher in juveniles than in adults. According to MANGRUM (1975), young animals have higher red cell values because the bones have greater erythropoietic activity. Regarding leukocytes, it was reported that young animals are more prone to excitement than adults, which may increase mobilization of lymphocytes by epinephrine released. This phenomenon may be accompanied by a slight to moderate increase of eosinophils too (POITOUT-BELISSENT, et al., 2000). WU et al. (2014) reported identical differences between juvenile and adult Tibetan monkeys. In 2008, studies performed in capuchin monkeys presented dissimilar results without obtaining statistical differences for these variables (FLAIBAN et al., 2008; WIRZ et al., 2008). Concerning the differences observed for band neutrophils, no similar results were reported in the literature. Given the fact that segmented neutrophils did not showed statistical difference between ages, the authors equate the possibility of differences observed for band neutrophils being a consequence of the statistical analysis done in a small sample with a 100 cell differential accounts and probably not clinically relevant.

Controversial results presented by different reports from different parts of the world support our hypothesis that local geographic specificities can influence hematological values and reinforce the idea that it is extremely important to make regional studies to better understand normal ranges, in order to contribute to the local improvement of species at risk. Furthermore, the differences between methods and laboratories also can influence the results.

In this study an anesthetic ketaminebased protocol was used for blood collection, consequently we cannot exclude its possible effect on the hematological values. Nevertheless, ketamine has been the drug of choice for anesthesia of primates due to its rapid effect, wide margin of safety, and relatively short duration effect (WINTERBORN, et al., 2008); therefore, the majority of studies that report hematological values on this species have also used the same drug for anesthetic purposes (WIRZ, 2008; TEIXEIRA, 2013; MOTA, 2016).

One of the limitations of the present study was the limited number of animals, which prevented a more specific approach, namely calculating hematologic RI by age and sex. Further studies with larger samples sizes are needed in order to completely characterize the bearded monkey hematological RI.
This research reported the first hematological profile of bearded capuchin monkeys (S. lidibinosus) in captivity in the state of Paraíba, Brazil. Regional climatic and dietary variations can possibly influence the hematologic profile. Consequently, it seems to be of considerable importance to carry out local studies in different regions. In conclusion, our results revealed that sex and age influence the hematological profile in bearded capuchin monkeys; therefore, such factors must be taken into account when interpreting a blood test on this species.

\section{ACKNOWLEDGEMENTS}

This work was supported by: European Investment Funds by FEDER/COMPETE/POCI - Operacional Competitiveness and Internationalization Programme, under Project POCI-01-0145-FEDER-006958 and National Funds by FCT - Portuguese Foundation for Science and Technology, under the projects UID/AGR/04033/2013 and UID/ MULTI/00211/2013.

\section{BIOETHICS AND BIOSSECURITY COMMITTEE APPROVAL}

The present study was approved by the Bioethics Council of the Universidade Federal de Campina Grande, Brazil (Authorization number 16232-1 of 18/08/2008; Protocol 95/2008), which follows the National Research Council Guide for the care of Laboratory Animals.

DECLARATION OF CONFLICTING
INTERESTS

The authors declared no potential conflicts of interest with respect to the research, authorship, and/or publication of this article.

\section{AUTHORS' CONTRIBUTIONS}

All authors contributed equally for the conception and writing of the manuscript. All authors critically revised the manuscript and approved of the final version.

\section{REFERENCES}

BLOBEL, G. A., ORKIN, S.H. Estrogen-induced apoptosis by inhibition of the erythroid transcription factor GATA-1. Journal of Molecular Cell Biology, v.16, p.1687-1694, 1996. Available from: $<$ https://www.ncbi.nlm.nih.gov/pubmed/8657144>. Accessed: Feb. 10,2018 .

BUCHL, S. J., HOWARD, B. Hematologic and serum biochemical and electrolyte values in clinically normal domestically bred rhesus monkeys (Macaca mulatta) according to age, sex and gravidity. Laboratory Animal Science, v.47, p.528-33, 1997. Available from: <http://www.ingentaconnect.com/contentone/ aalas $/ \mathrm{cm} / 1997 / 00000047 / 00000005 /$ art00012?crawler=true \&mi metype $=$ application/pdf $>$. Accessed: Nov. 10, 2017. 
CAROSI, M. et al. Display of proceptive behaviours in relation to urinary and fecal progestin levels over the ovarian cycle in female tufted capuchin monkeys. Hormones and Behavior, v.36, p.252-65, 1999. Available from: <https://s3.amazonaws. com/academia.edu.documents/33538107/Carosi_et_al_1999 Display_of_proceptive_behaviors_in_relation_to_urinary_and fecal_progestin_levels_over_the_ovarian_cycle_in_female_tuf. 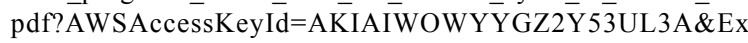 pires $=1515867756 \&$ Signature $=$ pgQvA $860 \mathrm{gaV} 4 \mathrm{hwOIz5obO}$ $2 \mathrm{oN} 3 \mathrm{Zo} \% 3 \mathrm{D} \&$ response-content-disposition=inline $\% 3 \mathrm{~B} \% 20$ filename\%3DDisplay_of_Proceptive_Behaviors_in_Relat.pdf $>$. Accessed: Nov. 10, 2017. doi: 0018-506X/99.

FLAIBAN, M. C., et al. Hematologic values of free-ranging Cebus cay and Cebus nigritus in Southern Brazil. International Journal of Primatology, v.29, p.1375-82, 2008. Available from: $<$ https://s3.amazonaws.com/academia.edu.documents/44619706/ Hematologic_Values_of_Free-ranging_Cebus20160411-253674fi6ba.pdf?AWSAccessKeyId=AKIAIWOWYYGZ2Y53UL3A $\&$ Expires $=1515868357 \&$ Signature $=$ AwLsQ3ZIAtEi55WdFE3 ZAjTkW1I\%3D\&response-content-disposition=inline $\% 3 \mathrm{~B} \% 20$ filename $\% 3$ DHematologic_Values_of_Free-ranging_Cebus.pdf $>$. Accessed: Nov. 10, 2017. doi: 10.1007/s10764-008-9290-5.

FONIO, A. Ueber ein neues Verfahren der Blutplattchenzahlung. Deustche Zeitschrieft Fur Chirurgie, 117: 176, 1912.

FRAGASZY, D. M., et al. The Complete Capuchin: the Biology of the Genus Cebus. University of Cambridge Press, Cambridge, 2004.

FRIEDRICHS, K. R., et al. ASVCP reference interval guidelines: determination of de novo reference intervals in veterinary species and other related topics. Veterinary Clinical Pathology, v.41, p.441-53, 2012. Available from: <https://www.ncbi.nlm.nih. gov/pubmed/23240820>. Accessed: Feb. 10, 2018. doi: 10.1111/ vcp. 12006 .

GEFFRÉ, A., et al. Reference value advisor: a new freeware set of macroinstructions to calculate RI with Microsoft Excel. Veterinary Clinical Pathology, v.40, p.107-12, 2011. Available from: <https:// www.ncbi.nlm.nih.gov/pubmed/21366659>. Accessed: Feb. 10, 2018. doi: 10.1111/j.1939-165X.2011.00287.x.

IHRIG, M., et al. Hematologic and serum biochemical reference intervals for the chimpanzee (Pan troglodytes) categorized by age and sex. Comparative Medicine, v.51,p.30-7,2001.Available from: $<$ http://www. ingentaconnect.com/contentone/aalas/cm/2001/00000051/00000001/ art00006?crawler=true >. Accessed: Nov. 10, 2017.

KENNEDY, R. C., et al. Nonhuman primate models to evaluate vaccine safety and immunogenicity. Vaccine, v.15, p.903-8, 1997. Available from: $<$ http://www.sciencedirect.com/science/article/pii/ S0264410X96002770>. Accessed: Nov. 10, 2017. doi: 10.1016/ S0264-410X(96)00277-0.

LARSSON, M. H. M. A, et al. Hematological values of Cebus apella anesthetized with ketamine. Brazilian Journal of Veterinary Research and Animal Science, v.36, p.131-5, 1997. Available from: <http://www.scielo.br/scielo.php?script=sci_artte xt\&pid=S1413-95961999000300005>. Accessed: Nov. 10, 2017. doi: 10.1590/S1413-95961999000300005.

MANGRUM, R. E. Manual of Hematology. Reston Publishing Company Inc., New York, p.7, 1975.
MARTINS, A. M. Jr, et al. Alu elements and the phylogeny of capuchin (Cebus and Sapajus) monkeys. American Journal of Primatology, v. 77(4), p.368-75, 2015. Available from: <http:// onlinelibrary.wiley.com/doi/10.1002/ajp.22352/abstract $>$. Accessed: Nov. 10, 2017. doi: 10.1002/ajp.22352.

MOTA, S. M., et al. Biometric values, C-reactive protein, and proteinogram of healthy blonde capuchin (Sapajus flavius) kept in northeast of Brazil. Journal of medical primatology, v. 45(6), p. 318-323, 2016. Available from: <https://onlinelibrary.wiley. com/doi/pdf/10.1111/jmp.12243>. Accessed: Nov. 10, 2017. doi: 10.1111/jmp.12243.

NUNES, E. S. H., et al. Blood biochemical indicators in young and adults Cebus apella of both sexes. Journal of Medical Primatology, v.37, p.12-17, 2008. Available from: <https://www. ncbi.nlm.nih.gov/pubmed/18199067>. Accessed: Nov. 10, 2017. doi: 10.1111/j.1600-0684.2007.00215.x.

NUNN, C. L., et al. J. Promiscuity and the primate immune system. Science, v.290, p.1168-70, 2000. Available from: $<$ https://www. ncbi.nlm.nih.gov/pubmed/11073457>. Accessed: Nov. 10, 2017.

POITOUT-BELISSENT, F. M., MCCARTNEY, J. E. Interpretation of hematology data in preclinical toxicological studies, In Schalm's Veterinary Hematology. FELDMAN, B. F., et al. Lippincott Williams and Wilkins, Philadelphia, 2000.

RAHAMAN, H., et al. Comparative haematology, haemochemistry and electrocardiography of slender loris and bonnet monkey. Laboratory Animals, v.9, p.69-78, 1975. Available from: <http:// journals.sagepub.com/doi/pdf/10.1258/002367775780994880>. Accessed: Nov. 10, 2017.

RIVIELLO, M. C., WIRZ, A. Haematology and blood chemistry of Cebus apella in relation to sex and age. Journal of Medical Primatology, v.30, p.308-12, 2001. Available from: <http:// onlinelibrary.wiley.com/doi/10.1034/j.1600-0684.2001.300604.x/ full>. Accessed: Nov. 10, 2017. doi: 10.1034/j.16000684.2001.300604.x.

ROSNER, J. M., et al. Body measurements, hematology and serum chemistry values of the adult Cebus apella monkey. Journal of Medical Primatology, v.15, p. 295-302, 1986. Available from: $<$ http://europepmc.org/abstract/med/3746888>. Accessed: Nov. $10,2017$.

TERPSTRA, A. H, et al. Estimation of HDL cholesteryl ester kinetic parameters in the Cebus monkey, an animal species with high plasma cholesteryl ester transfer activity. Atherosclerosis, v.88, p.243-8, 1991. Available from: <http://www.atherosclerosisjournal.com/article/0021-9150(91)90087-J/pdf>. Accessed: Nov. 10, 2017.

VIDEAN, E. N., et al. Effects of aging on hematology and serum clinical chemistry in chimpanzees (Pan troglodytes). American Journal of Primatology, v.70, p.327-38, 2008. Available from: $<$ http://onlinelibrary.wiley.com/doi/10.1002/ajp.20494/full $>$. Accessed: Nov. 10, 2017. doi: 10.1002/ajp.20494.

TEIXEIRA, M. G., et al. Hematologic and blood chemistry values of healthy Cebus flavius kept in northeast of Brazil. Journal of Medical Primatology, v.42(2), p.51-56, 2013. Available from: $<$ https://onlinelibrary.wiley.com/doi/pdf/10.1111/jmp.12036>. Accessed: Nov. 10, 2017. doi: 10.1111/jmp.12036. 
THEML, H., et al. Introduction to the physiology and pathophysiology of the hematopoietic system, In: Color Atlas of Hematology. THEML, et al. (eds). New York: Thieme, 2004.

WINTERBORN AN, et al. The efficacy of orally dosed ketamine and ketamine/mede- tomidine compared with intramuscular ketamine in rhesus macaques (Macaca mulatta) and the effects of dosing route on haematological stress markers. Journal of Medical Primatology, v.37, p.116-27, 2008. Available from: < https://onlinelibrary.wiley. com/doi/pdf/10.1111/j.1600-0684.2007.00234.x>. Accessed: Feb. 10, 2018. doi: 10.1111/j.1600-0684.2007.00234.x.
WIRZ, A., et al. Hematological and plasma biochemical values for captive tufted capuchin monkeys (Cebus apella). American Journal of Primatology, v.70, p.463-72, 2008. Available from: <https://pdfs. semanticscholar.org/2b60/bef5965acd90c93fec70d20fd46319499eef. pdf>. Accessed: Nov. 10, 2017. doi: 10.1002/ajp.20520.

WU, D., et al. Effects of age and sex on the hematology and blood chemistry of Tibetan Macaques (Macaca thibetana). Journal of the American Association for Laboratory Animal Science, v.53, p.1217, 2014. Available from: <http://www.ingentaconnect.com/content/ aalas/jaalas/2014/00000053/00000001/art00002?crawler=true\&mimet ype=application/pdf $>$. Accessed: Nov. 10, 2017. 